\title{
A Gold-Chromium-Cobalt Alloy for Sliding Contacts
}

\author{
E. A. Brandes
}

Fulmer Research Institute, Stoke Poges, England

A gold base alloy has been developed which can be precipitation hardened to make it suitable for use in sliding contacts. It is hard, strong and wear-resistant and has a low resistivity as well as a low contact resistance. The temperature coefficient of resistance can be varied and can be made low or zero at temperatures in the range 0 to $100^{\circ} \mathrm{C}$. Its development is summarised and its properties compared with those of alloys generally used for sliding contacts.

A sliding electrical contact should be of low and constant resistance. It should not tarnish, wear or form insulating films by polymerisation of organic material. Pure gold does not oxidise or catalyse organics, but it wears quickly and then gives erratic values for contact resistance. Gold has low contact resistance compared to that of other precious metals, as can be seen by values given by H. C. Angus (1) and E. M. Wise (2) plotted in Figure 1 for increasing loads. The relation between load and resistance in a contact is complex, a full treatment being given by R. Holm (3). He finds that the slope of the curves plotted as in Figure 1 are similar for most metals so that, from a single point, an estimate of the probable relation with load can be obtained.

A satisfactory gold-based contact alloy needs the increased hardness which can be achieved by alloying without loss of tarnish resistance and with minimum lowering of electrical conductivity. This combination of properties can be obtained by exploiting precipitation hardening in a system in which hardness and strength can result from the dispersion of a fine precipitate, leaving a solute-depleted matrix of virtually pure gold. In these circumstances, the con-

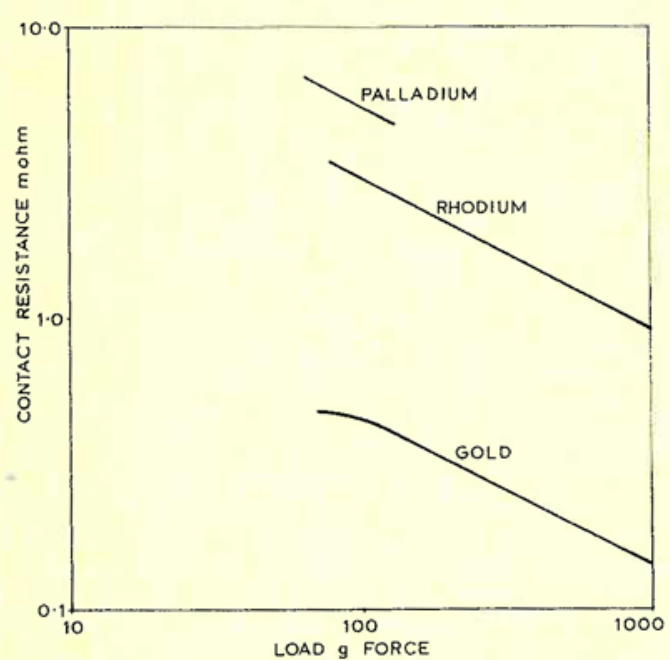

Fig. 1 (above) Resistivity of crossed wire contacts as a function of contact pressure $(1,2)$

Fig. 2 (right) The gold-chromium equilibrium diagram after E. Raub

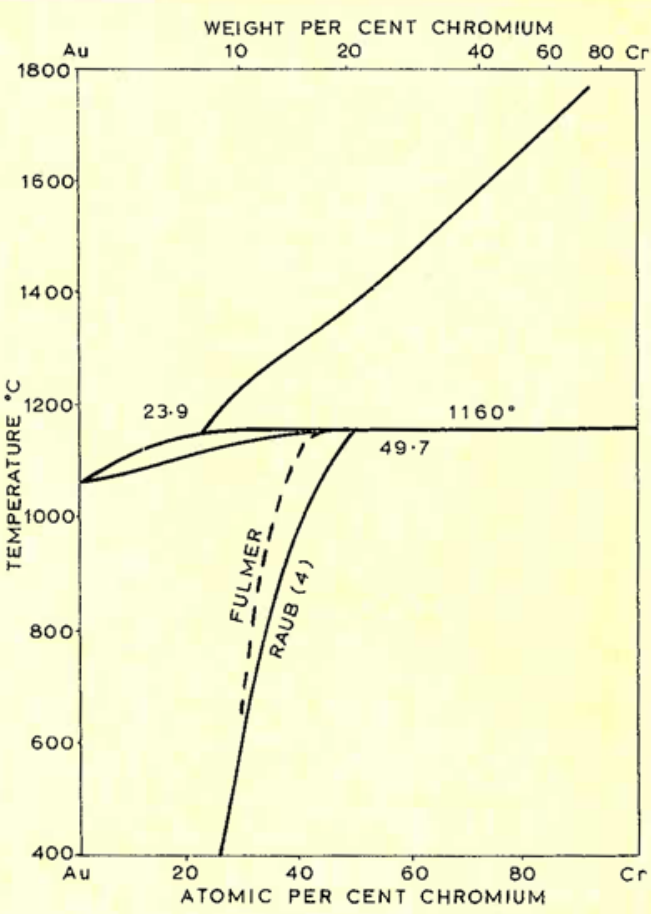




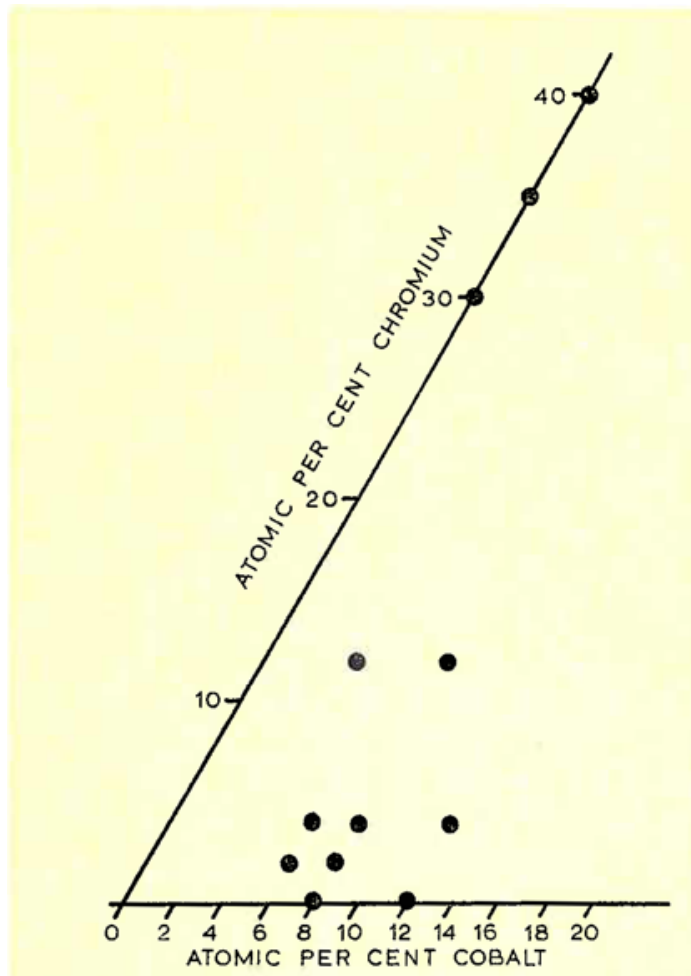

Fig. 3 Compositions investigated in the goldchromium-cobalt system

ductivity remains high. In the course of a research programme carried out for the Chamber of Mines a suitable alloy of this type has been developed.

\section{Binary Systems}

The first system examined for this purpose was gold-chromium. E. Raub's equilibrium diagram (4) for this system is shown in Figure 2. Alloys of $10,12.5$ and 15 weight per cent chromium should all be single phase at $1100^{\circ} \mathrm{C}$. However, in alloys made from high purity gold and chromium, the 15 per cent alloy was found still to contain primary chromium which persisted even after 5 hours' heat treatment at $1100^{\circ} \mathrm{C}$. The other compositions contained no chromium-rich phase and were therefore in agreement with the Raub diagram. The dotted line on Figure 2 is therefore more probably correct.

The binary alloys responded well to precipitation hardening but even after prolonged ageing at 250 to $350^{\circ} \mathrm{C}$ were of high electrical resistance, the specific resistance never falling below $100 \mu \mathrm{ohm} \mathrm{cm}$. Attention was therefore given to ternary systems in which the ternary addition could be utilised to reduce the total solute content in solid solution after ageing.

\section{Ternary Systems}

Work on the gold-chromium-titanium system was abandoned because titanium had the opposite effect to that intended; hardening was limited and titanium remained in solid solution, thus raising the resistivity. Much better results were obtained from the goldchromium-cobalt system, from which the compositions shown in Figure 3 were examined.

Tests in which solution treatment and ageing temperatures were varied led to the standardisation of heat treatment as solution treatment at $960^{\circ} \mathrm{C}$ followed by ageing at $250^{\circ} \mathrm{C}$. Later modifications of the alloys enabled a lower solution treatment temperature of $850^{\circ} \mathrm{C}$ to be used. The variation of hardness with ageing time is shown in Figure 4.

Lowering the chromium-to-cobalt ratio reduced the resistivity after hardening by reducing the residual solute content in the gold matrix. However, chromium cannot be removed completely as the binary gold-cobalt alloy is prone to discontinuous precipitation which causes brittleness. The optimisation of the system requires a balance between the ductility of the chromium alloys and the low resistivity of the cobalt alloys. Resistivities after ageing of the low chromium-cobalt alloys are listed in Table 1.

The alloy with 2 atomic per cent chromium and 8 atomic per cent cobalt has attractive properties, but for these compositions to be useful as sliding contact materials the brittleness caused by the discontinuous precipitation must be prevented. The precipitation structure causing the embrittlement is shown in Figure 5.

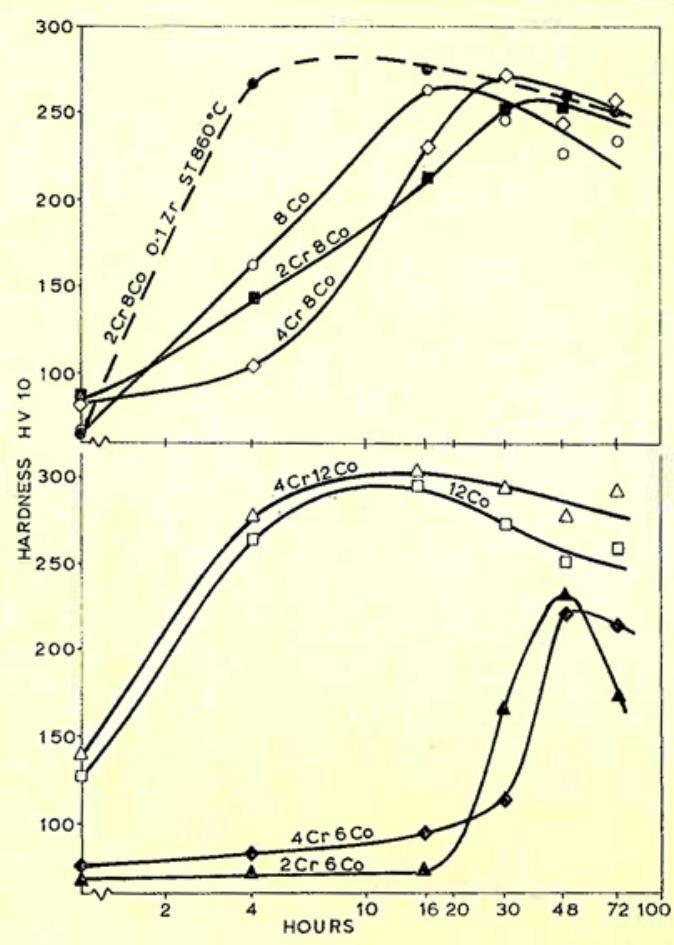

Fig. 4 Ageing curves for ternary Au-Cr-Co alloys (atomic per cent). Solution treated at $960^{\circ} \mathrm{C}$ and water quenched, aged at $250^{\circ} \mathrm{C}$ 
Table I

Resistivity and Hardness of Au-Cr-Co Alloys in Various Conditions

\begin{tabular}{|c|c|c|c|c|c|c|c|c|c|}
\hline \multicolumn{4}{|c|}{ Composition } & \multicolumn{6}{|c|}{ Condition } \\
\hline \multicolumn{2}{|c|}{$\mathrm{Cr}$} & \multicolumn{2}{|c|}{ Co } & \multicolumn{2}{|c|}{ Solution Treated $960^{\circ} \mathrm{CWO}$} & \multicolumn{4}{|c|}{ Solution Treated and Aged $250^{\circ} \mathrm{C}$} \\
\hline \multirow{2}{*}{$\begin{array}{l}\text { Atomic } \\
\text { per cent }\end{array}$} & \multirow{2}{*}{$\begin{array}{l}\text { Weight } \\
\text { per cent }\end{array}$} & \multirow{2}{*}{$\begin{array}{l}\text { Atomic } \\
\text { per cent }\end{array}$} & \multirow{2}{*}{$\begin{array}{l}\text { Weight } \\
\text { per cent }\end{array}$} & \multirow{2}{*}{$\begin{array}{l}\text { Resistivity } \\
\mu o h m \mathrm{~cm}\end{array}$} & \multirow{2}{*}{$\begin{array}{l}\text { Hardness } \\
\text { HV10 }\end{array}$} & \multicolumn{2}{|c|}{ At Peak } & \multicolumn{2}{|c|}{ Aged 72 Hours } \\
\hline & & & & & & $\begin{array}{l}\text { Resistivity } \\
\mu o h m ~ c m\end{array}$ & $\begin{array}{c}\text { Hardness } \\
\text { HV10 }\end{array}$ & $\begin{array}{l}\text { Resistivity } \\
\text { Hohm cm }\end{array}$ & $\begin{array}{c}\text { Hardness } \\
\text { HV10 }\end{array}$ \\
\hline 4 & $1 \cdot 14$ & 6 & 1.93 & 46.6 & 75.6 & 31.0 & 220 & 36.7 & 214 \\
\hline 4 & 1.16 & 8 & 2.62 & 52.2 & 83 & 31.2 & 270 & 24.1 & 257 \\
\hline 2 & 0.56 & 6 & 1.90 & 37.2 & 67.1 & 23.1 & 230 & 30.9 & 173 \\
\hline 2 & 0.57 & 8 & 2.58 & 44.3 & 83 & 18.6 & 250 & 14.2 & 250 \\
\hline
\end{tabular}

\section{Quaternary Alloys}

Discontinuous precipitation can, in some cases, be inhibited by trace additions of specific elements. The trace addition should have an atomic size 10 to 15 per cent larger than that of the matrix element, and thus have fairly limited solubility in the matrix. In these circumstances it will preferentially segregate to the grain boundary. The ternary composition of gold2 atomic per cent chromium-8 atomic per cent cobalt was chosen as a base to which these trace additions were made. The elements investigated were magnesium, indium, lithium, antimony, and zirconium at 0.1 atomic per cent additions. Yttrium and cerium were added at the 0.01 atomic per cent level. All of these additions had the effect of accelerating the onset of precipitation hardening during ageing at $250^{\circ} \mathrm{C}$; however, their influence on the control of discontinuous precipitation, varied considerably.

The most successful alloys were those with yttrium which could be hardened to $200 \mathrm{HV} 10$ without any appearance of grain boundary migration, and

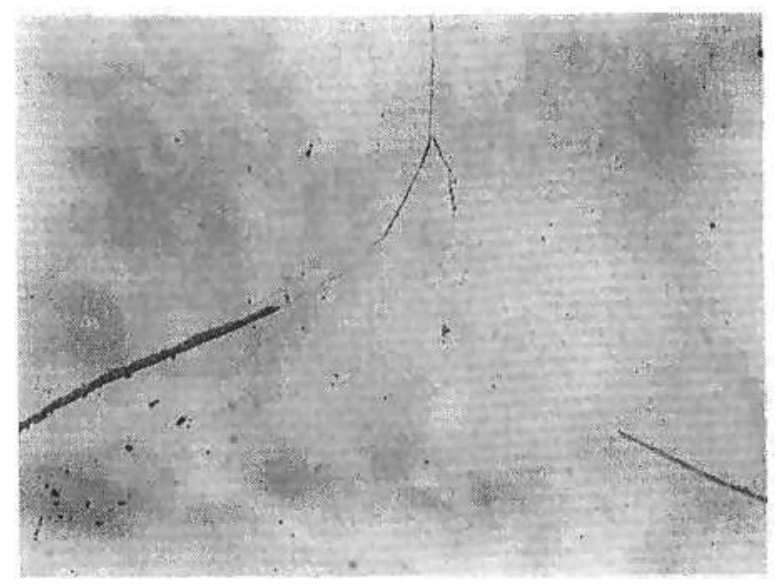

Fig. 5 Discontinuous grain boundary precipitation in a gold-4 atomic per cent chromium-8 atomic per cent cobalt alloy after solution treatment at $960^{\circ} \mathrm{C}$, water quenching and ageing for 30 hours at $250^{\circ} \mathrm{C}$ those with zirconium which could be hardened to at least 250 HV10 with boundaries free from discontinuous precipitation.

After ageing 16 hours at $250^{\circ} \mathrm{C}$, the hardness of the zirconium-containing alloy was $276 \mathrm{HV} 10$ and its grain boundaries were free of discontinuous precipitation, while the same composition without trace alloy addition had a hardness of $213 \mathrm{HV} 10$ and showed grain boundary thickening which heralds the onset of discontinuous precipitation. Grain boundary conditions of the alloys with magnesium, yttrium and zirconium trace additions are illustrated by the microstructures in Figure 6. The effect of the zirconium addition on hardening during ageing is shown for the $\mathrm{Au}-2 \mathrm{Cr}-8 \mathrm{Co}$ alloy, with and without zirconium, in Figure 7. The solution treatment temperature of $960^{\circ} \mathrm{C}$ was found to give large grain sizes; reducing this to $850^{\circ} \mathrm{C}$ had little effect on the hardening during ageing but was beneficial in preventing excessive grain growth.

The progress of selection from binary to quaternary systems led to the final choice of the preferred composition alloy, identified as $\mathrm{J} 275$, which contains 2 atomic per cent chromium, 8 atomic per cent cobalt and 0.1 atomic per cent zirconium ( 0.6 weight per cent chromium, 2.6 weight per cent cobalt and 0.05 weight per cent zirconium).

\section{Assessment of the Preferred Alloy}

Apart from the hardness values already shown in Figure 7, tensile tests on alloy J275 were made on $0.25 \mathrm{~mm}$ diameter wires $10 \mathrm{~cm}$ long. The elongations varied from 0.1 to 2.0 per cent, depending on surface finish. The 0.1 per cent proof stress and the ultimate tensile strength for various heat treatment conditions are shown in Table II.

\section{Electrical Resistance}

The electrical resistance of the preferred quaternary alloy J275 decreases on ageing to about $22 \mu \mathrm{ohm} \mathrm{cm}$. 

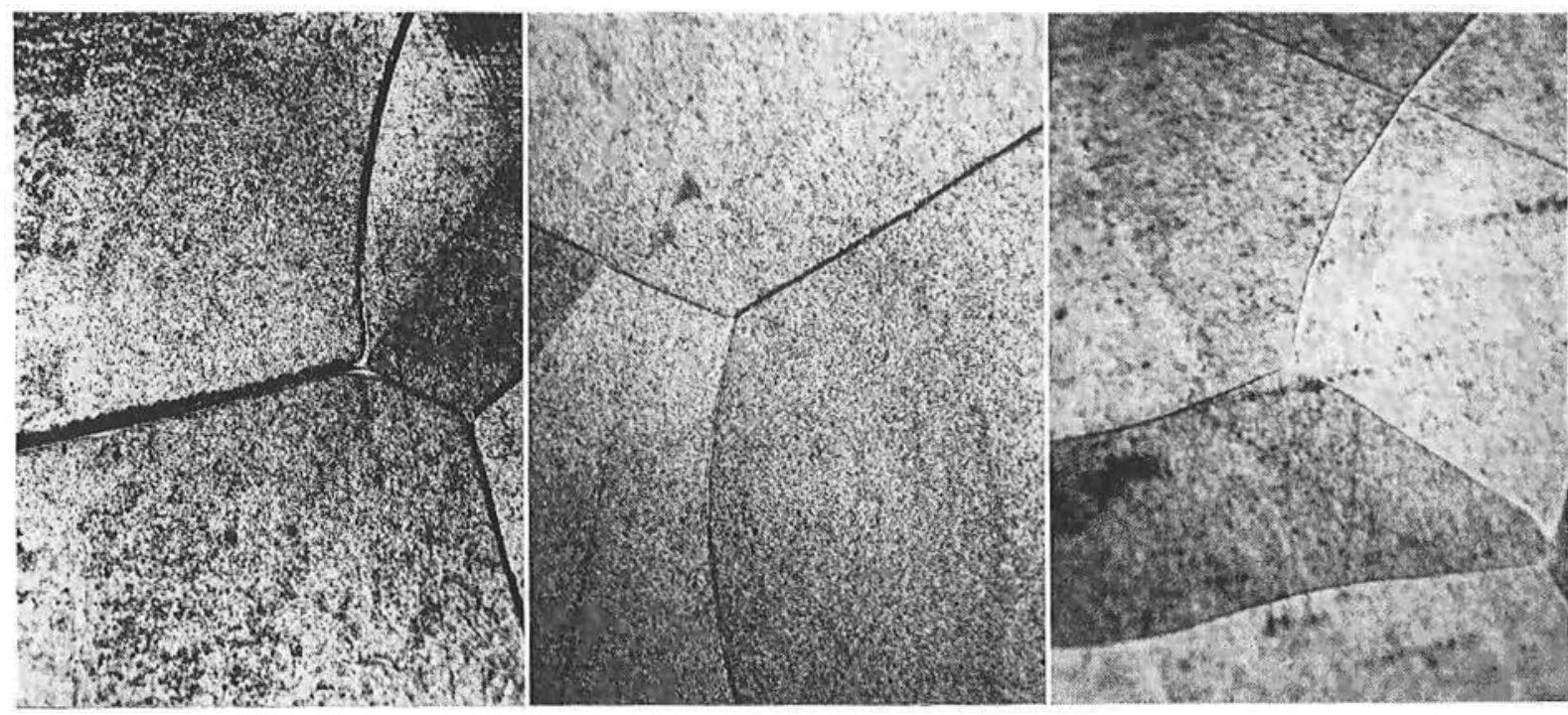

Fig. 6 Grain boundary conditions in a gold-2 atomic per cent chromium-8 atomic per cent cobalt alloy after solution treatment at $960^{\circ} \mathrm{C}$, water quenching and 16 hours ageing at $250^{\circ} \mathrm{C}$ with quaternary trace additions.

Left: 0.1 at. $\% \mathrm{Mg}$, severe discontinuous precipitation Centre: 0.01 at. $\%$ Y, slight grain boundary precipitation

Right: 0.1 at. $\% \mathrm{Zr}$, precipitation free boundaries

In Table III the resistivity of this alloy during precipitation is compared with two standard commercial contact resistance wire materials-Johnson Matthey gold-copper-silver alloy, JMM 625, and the palladium-platinum-gold-silver alloy, JMM 77.
Variation of Resistance with Temperature

The change in resistivity of alloy $\mathrm{J} 275$ between room temperature and $100^{\circ} \mathrm{C}$ has been measured for various heat treatment conditions. The temperature coefficient of resistance is nearly constant over this

Table II

Tensile Tests on $0.25 \mathrm{~mm}$ Diameter Wire J275 Alloy after Solution Treatment at $850^{\circ} \mathrm{C}$ Water Quench and Ageing at $250^{\circ} \mathrm{C}$

\begin{tabular}{c|c|c|c|c}
\hline \multirow{2}{*}{$\begin{array}{c}\text { Ageing Time } \\
\text { hours }\end{array}$} & \multicolumn{2}{|c|}{0.1 per cent Proof Stress } & \multicolumn{2}{c}{ Ultimate Tensile Stress } \\
\cline { 2 - 4 } & $\mathrm{MN} / \mathrm{m}^{2}$ & tonf/in ${ }^{2}$ & $\mathrm{MN} / \mathrm{m}^{2}$ & tonf/in $^{2}$ \\
\hline 0 & 311 & 20.1 & 329 & 21.3 \\
2 & 349 & 22.6 & 407 & 26.4 \\
4 & 356 & 23.1 & 410 & 26.5 \\
8 & 382 & 24.7 & 438 & 28.4 \\
16 & 527 & 34.1 & 569 & 36.8 \\
24 & 592 & 38.3 & 640 & 41.4 \\
30 & 620 & 40.1 & 690 & 44.7 \\
& & & &
\end{tabular}

Electrical Resistance at Room Temperature of Au-Cr-Co-Zr Alloy J275 Compared with Standard Contact Alloys

\begin{tabular}{l|c|c|c|c}
\hline \multicolumn{1}{c|}{ Alloy } & \multicolumn{3}{|c}{ Resistance at Room Temperature in $\mu$ ohm $\mathrm{cm}$} \\
\cline { 2 - 4 } & Solution Treated $850^{\circ} \mathrm{C}$ and Water Quenched & \multicolumn{3}{|c}{ Ageing at $240^{\circ} \mathrm{C}$ in hours } \\
\hline J 275 & 43.5 & 4 & 8 & 10 \\
\hline JMM 625 & - & 39.8 & 37.2 & 29.0 \\
\hline JMM 77 & $37.5 \star$ & 22.2 & $14.0 \star$ at $250 \mathrm{HV} 10$ \\
\hline
\end{tabular}

$\star$ Temperatures and times not given 
Table IV

Contact Resistances for J275 Compared with Standard Alloy Sliding Resistance Materials Substrate Cupro-Nickel, Rubbing Speed $8 \mathrm{~cm} / \mathrm{s}$, Load 15g Force, Resistance in mohm. Running Times 40-72 hours

\begin{tabular}{|c|c|c|c|c|}
\hline Alloy & $\begin{array}{c}\mathrm{J} 275 \\
\mathrm{Au}-\mathrm{Co} \cdot \mathrm{Cr}-\mathrm{Zr}\end{array}$ & Pd- & $\begin{array}{l}77 \\
\mathrm{Au}-\mathrm{Ag}\end{array}$ & $\begin{array}{l}\mathrm{JMM} 625 \\
\mathrm{Au}-\mathrm{Cu}-\mathrm{Ag}\end{array}$ \\
\hline Condition & $\begin{array}{c}\text { Solution Treated } \\
850^{\circ} \mathrm{C} \mathrm{W.Q.} \mathrm{Aged} \\
250^{\circ} \mathrm{C} 30 \text { h. } 270 \mathrm{HV}\end{array}$ & $\begin{array}{c}\text { Solution Treated } \\
210 \mathrm{HV}\end{array}$ & $\begin{array}{c}\text { Solution Treated } \\
\text { W.Q. Aged } 450^{\circ} \mathrm{C} \\
2 \text { h. } 320 \mathrm{HV}\end{array}$ & $\begin{array}{l}\text { Hardness } \\
250 \mathrm{HV} 10\end{array}$ \\
\hline $\begin{array}{l}\text { Maximum contact } \\
\text { resistance } \\
\text { measured }\end{array}$ & 15 & 20 & 21 & 440 \\
\hline $\begin{array}{l}\text { Minimum contact } \\
\text { resistance } \\
\text { measured }\end{array}$ & 8 & 10 & 7 & 8 \\
\hline Range & 7 & 10 & 14 & 432 \\
\hline Number of readings & 12 & 12 & 5 & 12 \\
\hline Mean reading & 10 & 14 & 14 & 127 \\
\hline $\begin{array}{l}\text { Standard mean } \\
\text { deviation }\end{array}$ & 2.1 & 3.1 & 5 & 164 \\
\hline
\end{tabular}

range, and depends very critically on heat treatment. The alloy in the solution-treated condition has a negative coefficient; ageing at progressively higher temperatures producing increasingly positive coefficients. Ageing for 2 hours at $250^{\circ} \mathrm{C}$ after solution treatment produces a material with practically no change in resistance from room temperature to $100^{\circ} \mathrm{C}$. This might be a valuable property for some applications. The percentage changes of resistance for a range of heat treatments are plotted in Figure 8.

\section{Sliding Contact Resistance}

The apparatus used for measuring the sliding contact resistance was similar to that described by H. C. Angus (1). It consisted of a 56/44 cupronickel cylinder rotated at 60 revolutions per minute against which gold wires were pressed at a fixed load. The roller was 1 inch $(2.54 \mathrm{~cm})$ diameter giving a wiping speed of $8.0 \mathrm{~cm} / \mathrm{s}$. In most of the tests a $15 \mathrm{~g}$ loading force was used. The springs acted as current connections and very light copper wires were spot welded on near the contacts to act as potential leads. The tests were run for times up to 72 hours, readings being taken at increasing intervals during the run.

The range, average and standard mean deviation of the results for the alloy $\mathrm{J} 275$ fully heat treated and for some standard contact wires are shown in Table IV.

These tests showed that as a sliding contact material the new alloy compared well with presently available alloy wires.
Some initial tests were made against a gold-plated roller. At 3 gram force load, generally low (2 to $8 \mathrm{mohm}$ ) contact resistances were obtained but readings were very erratic. This was due to the pickup of the soft gold plate on to the harder contact wire. At $15 \mathrm{~g}$ force the wires rapidly cut through the soft gold plate, and the tests were therefore abandoned.

\section{Solderability}

Solderability was assessed by means of the G.E.C. Meniscograph Mk3 solderability tester. This recorded the force acting on a wire dipped into a

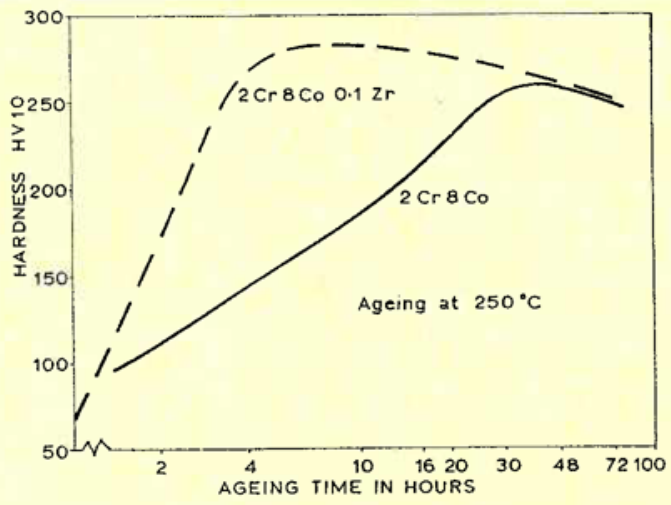

Fig. 7 Age hardening of a gold-2 atomic per cent chromium-8 atomic per cent cobalt alloy with and without 0.1 atomic per cent zirconium. The zirconium free alloy was solution treated at $960^{\circ} \mathrm{C}$ and water quenched; the zirconium-containing alloy solution was treated at $850^{\circ} \mathrm{C}$ and water quenched 


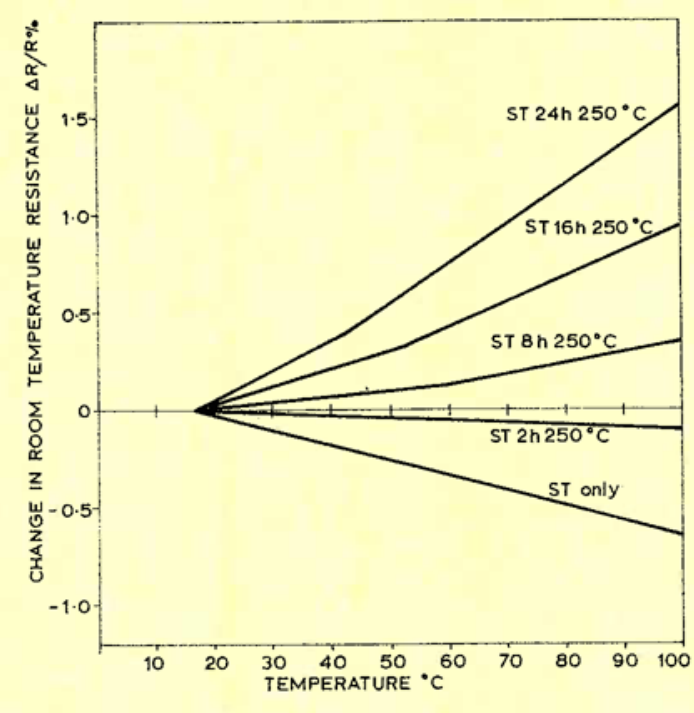

Fig. 8 Change of room temperature resistance up to $100^{\circ} \mathrm{C}$ for various heat treatments of the goldchromium-cobalt-zirconium alloy $\mathrm{J} 275$

molten bath of $60 / 40$ solder at $235^{\circ} \mathrm{C}$ in the presence of a non-activated 25 per cent resin flux. Initially an up-thrust on the wire is recorded as the wire depresses the surface of the liquid without wetting, i.e. the meniscus is pushed down; this is shown as a negative reading. As wetting takes place the meniscus gradually comes up to an equilibrium position and during this stage the reading becomes positive and approaches a steady value. A reasonable wetting time is taken as 2 seconds and all the results are therefore given as the force in micronewtons experienced by the wire 2 seconds after immersion. Several dips were made for each wire condition, and the results are averages. Usually the repeats were close together. Variable results are noted. Tests were made for untreated wires, and for the same wires after etching in 50/50 hydrochloric acid/water at $20^{\circ} \mathrm{C}$ for 15 seconds followed by washing and drying, and for an alkali electrolytic etch with the wire as cathode at $4 \mathrm{~A} / \mathrm{dm}^{2}$ for 5 minutes at $20^{\circ} \mathrm{C}$. The cathodic etch was followed by an anodic etch at $1 \mathrm{~A} / \mathrm{dm}^{2}$ at $20^{\circ} \mathrm{C}$. for 1 second, followed by washing.

The solderability results are set out in Table V.

The solution-treated alloy has a solderability comparable with that of pure gold but this decreases on ageing up to 16 hours at $250^{\circ} \mathrm{C}$ and then becomes slightly better. The electrolytic etch to remove any chromic oxide film formed during heat treatment improved solderability. The solderability revealed by the test is not high but no difficulty was found in practice with making soldered joints, as for instance those that were required in setting up the contact resistance tests. A few solderability tests were made on the zirconium-free alloy; apart from a somewhat greater scatter, they did not differ from those for the quaternary alloy.

\section{Summary of Properties}

The most promising alloy developed for sliding contact applications, known as Alloy J275, has therefore the following properties.

It contains 0.6 weight per cent chromium, 2.6 weight per cent cobalt, and 0.05 weight per cent zirconium, balance gold.

Its solution treatment involves heating to $850^{\circ} \mathrm{C}$, water quenching and ageing for 30 hours at $250^{\circ} \mathrm{C}$. If the solution treatment is carried out in air some surface oxide may need to be removed.

Its resistivity at room temperature when given this

Table V

Solderability as Force in $\mu \mathrm{N} 2$ Seconds after Dipping into $60 / 40$ Solder at $235^{\circ} \mathrm{C}$ Non-activated Resin Flux

\begin{tabular}{|c|c|c|c|c|}
\hline \multirow[t]{2}{*}{ Wire } & \multirow[t]{2}{*}{ Condition } & \multicolumn{3}{|c|}{ Force $\mu \mathrm{N}$ (upthrust negative) } \\
\hline & & Untreated & $\begin{array}{c}\text { Hydrochloric } \\
\text { Etch }\end{array}$ & $\begin{array}{c}\text { Electrolytic } \\
\text { Etch }\end{array}$ \\
\hline Gold & $\begin{array}{l}\text { As drawn } \\
\text { Annealed }\end{array}$ & $\begin{array}{l}257 \\
305\end{array}$ & $\begin{array}{l}195 \\
285\end{array}$ & $\begin{array}{l}300 \\
253\end{array}$ \\
\hline $\begin{array}{l}\text { Alloy } \\
\text { J } 275\end{array}$ & $\begin{array}{l}\text { Solution treated } 850^{\circ} \mathrm{C} \mathrm{W.Q.} \\
\mathrm{ST}+2 \text { h. } 250^{\circ} \mathrm{C} \\
\mathrm{ST}+8 \text { h. } 250^{\circ} \mathrm{C} \\
\mathrm{ST}+16 \text { h. } 250^{\circ} \mathrm{C} \\
\mathrm{ST}+24 \text { h. } 250^{\circ} \mathrm{C}\end{array}$ & $\begin{array}{r}228 \\
90 \\
-68 \\
-170 \\
-125\end{array}$ & $\begin{array}{r}210 \\
125 \\
50 \\
-65 \\
-100 \star\end{array}$ & $\begin{array}{c}93 \\
220 \star \\
0 \\
-70 \\
+50\end{array}$ \\
\hline
\end{tabular}

$\star$ Means of rather scattered results 
heat treatment is about $24 \mu \mathrm{ohmcm}$. The change of resistance with temperature depends very much on the heat treatment given. For the above heat treatment the change from room temperature to $100^{\circ} \mathrm{C}$ will be about 1.5 per cent. For about 2 hours ageing at $250^{\circ} \mathrm{C}$ the change over this temperature interval is very small.

Tested against a moving cupro-nickel substrate with a contact force of $15 \mathrm{~g}$, the contact resistance was 10 milliohms. This value was reproducible since the standard deviation of 12 results was 2.1 milliohms.

The solderability of the alloy was very dependent upon ageing time. Tests showed the solderability of the fully aged material to be poor compared with pure gold, but in practice soldered joints could be made easily by hand.

For the heat treatment given above the hardness is about 270 Vickers. The 0.1 per cent proof stress for this heat treatment is $620 \mathrm{MN} / \mathrm{m}^{2}\left(40.1\right.$ tonf $\left./ \mathrm{in}^{2}\right)$ and the ultimate tensile strength is $690 \mathrm{MN} / \mathrm{m}^{2}(44.7$ tonf $\left./ \mathrm{in}^{2}\right)$. Elongation has not been determined.
Brittleness results from too high a solution treatment temperature or from excessive grain growth.

\section{Conclusion}

A gold alloy has been developed which because of its response to precipitation heat treatment can be made particularly suitable as a sliding contact. It is hard, strong, and wear-resistant, has a low contact resistance and resistivity and at room temperature it is completely tarnish-resistant. The temperature coefficient of resistance is well characterised and in some heat treatment conditions can be made very low or zero for temperature fluctuations around ambient.

\section{References}

1 H. C. Angus, Trans. Inst. Metal Finishing, 1962, 39, 1

2 E. M. Wise, "Gold", D. van Nostrand Co, New York, 1964

3 R. Holm, "Electric Contacts", Springer Verlag, Berlin 1967

4 E. Raub, Z. Metallkunde, 1960, 51, 290

\section{Gold Brazing in the Space Shuttle Engines}

The production of the three main engines for the space shuttle is now nearing completion by the Rocketdyne Division of Rockwell International at Canoga Park, California, under a contract from the National Aeronautics and Space Administration. While a number of joints are electron-beam or tungsten-arc welded, many thousands of assemblies have been furnace brazed in a hydrogen atmosphere with several types of gold brazing alloys to ensure high strength and resistance to corrosion.

Inconel 625 was chosen for a number of components, including the main injection elements, and these were brazed with $70 \mathrm{Au}-22 \mathrm{Ni}-8 \mathrm{Pd}$ alloy, while the $304 \mathrm{~L}$ stainless steel parts of the injector face plate were previously sub-assembled by brazing with $50 \mathrm{Au}-25$ Ni-25 Pd alloy.

The nozzle assembly is constructed from 1086 tapered and shaped tubes in a high nickel austenitic stainless steel, brazed together as a unit and supported by bands of Inconel 718 with Inconel 903 structural rings. Ageing cycles to develop the full properties of these alloys imposed the need for several stages of brazing at various temperatures, the alloys used ranging from $70 \mathrm{Au}-22 \mathrm{Ni}-8 \mathrm{Pd}$ to $18 \mathrm{Au}-25 \mathrm{Mn}-6 \mathrm{Pd}-6 \mathrm{Ni}-45$ $\mathrm{Cu}$. Over 15 pounds of these alloys were used to join more than 10,000 feet of tubing to the Inconel jacket, with a further 2160 brazed joints where the tube ends were attached to the manifold.

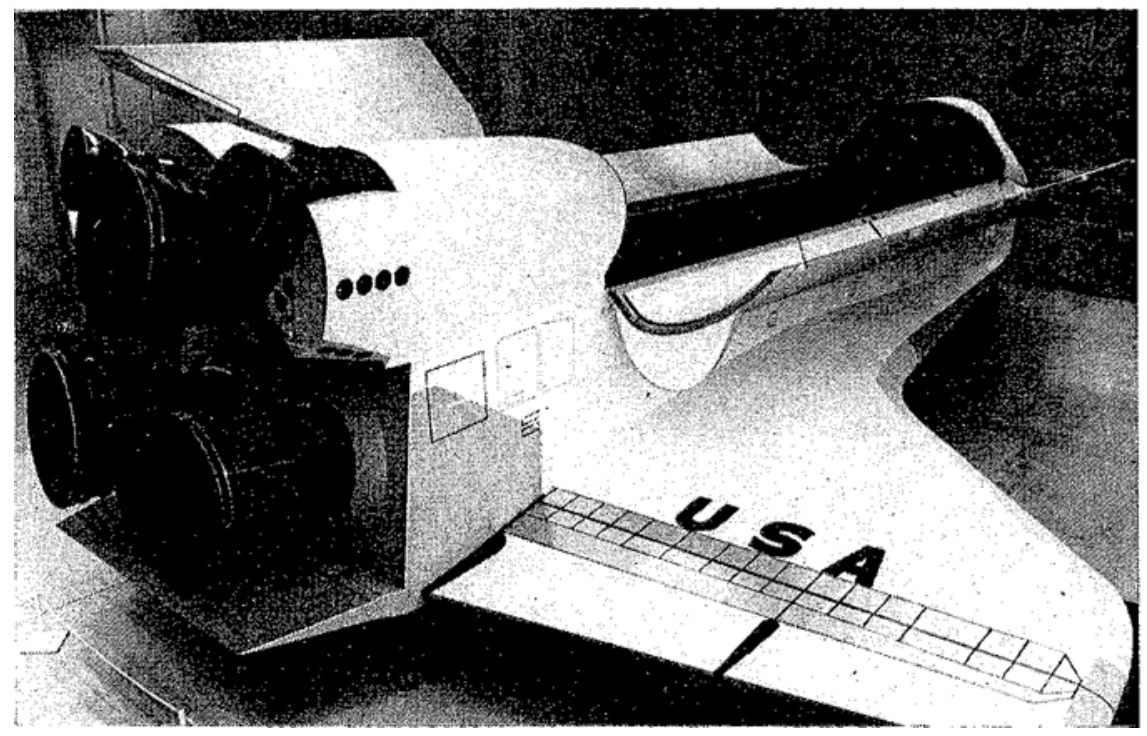

A full-scale mock-up of the space shuttle orbiter, a winged, manned vehicle about the size of a DC9 aircraft. Gold alloy brazing has been used extensively in the assembly of the three main engines 